\title{
On ant-like Synemosyna Hentz, 1846 spiders from Bolivia, with indirect evidence for polymorphic mimicry complexes (Araneae: Salticidae: Simonellini)
}

\author{
Robert PERGER ${ }^{1, *}$, Gonzalo D. RUBIO ${ }^{2} \&$ Charles R. HADDAD ${ }^{3}$ \\ ${ }^{1}$ Colección Boliviana de Fauna, La Paz, Bolivia. \\ ${ }^{2}$ National Research Council of Argentina (CONICET), Experimental Station of \\ Agriculture (EEA-INTA), R 14, Km 1085, Cerro Azul, Misiones, Argentina. \\ ${ }^{3}$ Dept of Zoology \& Entomology, University of the Free State, P.O. Box 339, \\ Bloemfontein 9300, South Africa. \\ *Corresponding author: robertperger@hotmail.com \\ 2Email: gonzalodrubio@gmail.com \\ ${ }^{3}$ Email: haddadcr@ufs.ac.za \\ ${ }^{1}$ urn:1sid:zoobank.org:author:1019F079-5C55-4467-80BE-DBB75A50F10F \\ ${ }^{2}$ urn:1sid:zoobank.org:author:07433A47-CD98-4C62-83D1-0568B6C98A24 \\ ${ }^{3}$ urn:lsid:zoobank.org:author:417ED537-9B99-48BD-B2AB-CC27E762C850 \\ ${ }^{1} \odot$ https://orcid.org/0000-0001-9930-9638
${ }^{2} \odot$ https://orcid.org/0000-0002-4223-2980
${ }^{3} \odot$ https://orcid.org/0000-0002-2317-7760
}

\begin{abstract}
Three species of Synemosyna Hentz, 1846 were recorded during a survey in five Bolivian forest ecoregions: S. aurantiaca (Mello-Leitão, 1917), S. myrmeciaeformis (Taczanowski, 1871) and S. nicaraguaensis Cutler, 1993. Synemosyna aurantiaca and S. nicaraguaensis are recorded for Bolivia for the first time and the previously unknown male of $S$. nicaraguaensis is described and illustrated. The habitus and the genitalia of the female of $S$. myrmeciaeformis are illustrated for the first time. Synemosyna aurantiaca occurs in semi-deciduous forests south of $18^{\circ} \mathrm{S}$ and S. myrmeciaeformis in the Bolivian Yungas forest and ecoregions of the Amazon biome north of $16^{\circ}$ S. Synemosyna nicaraguaensis is possibly an Andean species that enters into the moist Isthmian forests of Central America. Several potential mimicry complexes with two broad patterns were observed: sex-specific polychromatic mimicry (S. nicaraguaensis), and transformational mimicry involving smaller orange and larger brown to dark-brown forms (S. aurantiaca and S. myrmeciaeformis).
\end{abstract}

Keywords. Myrmecomorphic, Neotropical, Pseudomyrmex, systematics, South America.

Perger R., Rubio G.D. \& Haddad C.R. 2021. On ant-like Synemosyna Hentz, 1846 spiders from Bolivia, with indirect evidence for polymorphic mimicry complexes (Araneae: Salticidae: Simonellini). European Journal of Taxonomy 748: 67-88. https://doi.org/10.5852/ejt.2021.748.1343 


\section{Introduction}

Ant-mimicking (or myrmecomorphic) spiders have fascinated many naturalists over centuries and are a promising group to study mimicry and evolution through natural selection (Nelson \& Jackson 2012; Ceccarelli 2013). In the family Salticidae Blackwall, 1841, strong ant (or wasp) mimicry has evolved at least 12 times (Maddison 2015), and mimetic specialization to an ant-like appearance has reached an extreme within Synemosyna Hentz, 1832 (Peckham \& Peckham 1892; Oliveira 1988). Several species of Synemosyna were cited for their strong resemblance to members of the ant genus Pseudomyrmex Lund, 1831 (see Cushing 1997 for a review).

The genus Synemosyna comprises 17 species; eight species in North and Central America and ten species in South America (Brazil six spp.; Colombia four spp.; Venezuela and French Guiana two spp.; Argentina and Suriname one sp.) (World Spider Catalog 2020). Knowledge of the taxonomy, morphology and ecoregion distribution of species of Synemosyna may provide an essential basis for future studies on mimicry (e.g., McIver \& Stonedahl 1993). However, these fields remain poorly understood (Cutler 1981a). For example, there are neither distributional records for vast areas of Amazonian and Andean forests, nor information on ecoregion affinities in the literature, hampering the analysis of biogeographical and mimetic patterns.

Bolivia encompasses over 12 ecoregions, including the megadiverse Amazon and Yungas rainforests, and is one of the 10 to 15 most biodiverse countries of the world (Ibisch \& Mérida 2003). The distribution of plants, vertebrates (Ibisch \& Mérida 2003) and invertebrates (Pearson et al. 1999; Wappes et al. 2011; Perger \& Perger 2017) indicates that the high biological diversity is attributed to high species turnover between the large number of ecoregions. However, despite high levels of ecological and biological diversity, only one of the ten South American species of Synemosyna has been recorded from Bolivia. In Galiano's $(1966,1967,1971)$ revisions of the Neotropical myrmecomorphic Salticidae, no Bolivian specimens were included. Synemosyna myrmeciaeformis (Taczanowski, 1871) is the only species that has been reported from Bolivia, from the Amazon rainforest in Beni Dept (Cutler 1981a).

In this work, we report on the results of a survey for species of Synemosyna in primary forest in five Bolivian forest ecoregions. The ecoregion affinities of the species are briefly described, and indirect evidence for polymorphic mimicry complexes provided.

\section{Material and methods}

The sampling of spiders and ants was conducted in 12 primary forest sites in five forest ecoregions of Bolivia (Amazon, Yungas, Chiquitano, Bolivian Tucuman forest and Inter-Andean Bolivian Tucuman forest, according to the ecoregion classification of Navarro \& Ferreira 2011) (Figs 1-2). Spiders and ants were collected with a beating tray with a one $\mathrm{m}^{2}$ white sheet from vegetation up to $1.85 \mathrm{~m}$ high. For beating, mid- and understorey branches were sharply struck with a stout stick, while holding the beating tray beneath them to catch falling spiders and ants.

Photographs of live spiders and ants and their habitats were taken with a Panasonic Lumix GX-80 system camera fitted with a Panasonic H-HS3030 macro lens. Colour was described from photographs of live specimens, as specimens stored in ethanol may lose their colour. Spiders and ants were euthanised with ethyl acetate and stored in $80 \%$ ethanol. Preserved specimens were examined under both dissecting microscopes and a compound microscope with reflected light, and identified using original and redescriptions, and keys (e.g., Taczanowski 1871; Peckham \& Peckham 1892; Mello-Leitão 1933; Galiano 1966, 1967, 1971; Cutler 1985). Photos of preserved specimens were taken with the Visionary Digital Passport II Imaging system at the Zoological Museum, University of Hamburg, Germany. 
Female genitalia were dissected as in Levi (1965), examined after digestion in $\sim 15 \%$ sodium hydroxide $(\mathrm{NaOH})$ solution, and clarified in clove oil to examine the internal structures. Temporary preparations were observed and photographed by G.R. using a Leica DM500 compound microscope and a Leica M60 stereo microscope. Structures were sketched on incident light photograph models using a computer system for drawing and treatment of the image (Wacom digitizer tablet with GIMP, free software). All measurements, which were obtained with an ocular micrometer, are given in millimetres. Body length measurement refers to the distance from the anterior margin of the carapace to the posterior margin of the opisthosoma.

\section{Abbreviations}

$$
\begin{aligned}
\mathrm{AER} & =\text { anterior eye row } \\
\mathrm{ALE} & =\text { anterior lateral eyes } \\
\mathrm{AME} & =\text { anterior median eyes } \\
\mathrm{BL} & =\text { body length } \\
\mathrm{PE} & =\text { posterior eyes }
\end{aligned}
$$

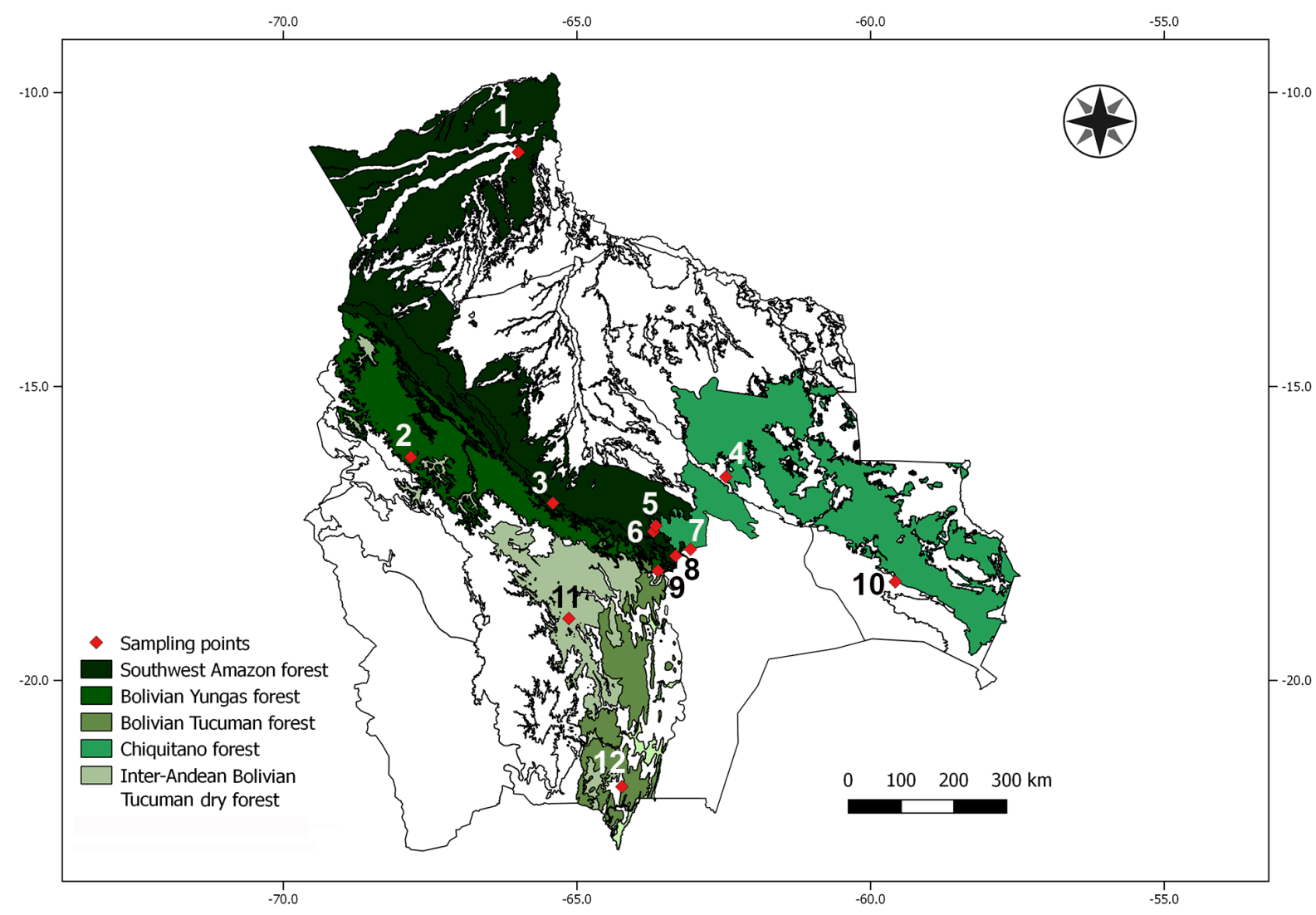

Fig. 1. Sampled locations and ecoregions according to the regionalization by Navarro \& Ferreira (2011), map produced with QGIS (ver. 2.14.3, http://www.qgis.org/en/site/). 1. Riberalta, Beni Dept. 2. Villa Teresa, La Paz Dept. 3. Villa Tunari, Cochabamba Dept. 4. Santa Rosa de la Mina, Santa Cruz Dept. 5. Santa María la Antigua, Santa Cruz Dept. 6. Cafetal, Buena Vista, Santa Cruz Dept. 7. Cotoca, Santa Cruz Dept. 8. La Guardia, Santa Cruz Dept. 9. Bermejo, Santa Cruz Dept. 10. Santiago de Chiquitos, Santa Cruz Dept. 11. Teja Huasi, Chuquisaca Dept. 12. Arambulo, Tarija Dept. 


\section{Arachnological collections}

$\mathrm{CBF}=$ Colección Boliviana de Fauna, La Paz, Bolivia (R. Perger)

IBSI-Ara $=$ Instituto de Biología Subtropical, Misiones, Argentina (G. Rubio)

MEL $=$ Museo Entomológico de León, Nicaragua (J.-M. Maes)

PAS $=$ Museum and Institute of Zoology of the Polish Academy of Sciences, Warsaw, Poland (W. Wawer)

\section{Ecoregion distribution}

Distributional records without coordinates were georeferenced via the gazetteers GeoLocator (http://tools.freeside.sk/geolocator/geolocator.html) and GeoNames (http://www.geonames.org/). The ecoregion affinities of the species at a continental level were investigated by visualizing the coordinates and shapefiles of the regionalization of Neotropical ecoregions by Olson et al. (2011) by using the geographic information system, QGIS (ver. 2.14.3, http://www.qgis.org/en/site/). For Bolivian ecoregions, the shapefile from Navarro \& Ferreira (2011) was used, as field observations of forest types suggested that this regionalization is more consistent than that from Olson et al. (2011). Geographic coordinates are shown in decimal degrees with reference datum WGS84, and elevation in meters above sea level (m a.s.l.).

\section{Ant mimicry}

In this study, an indirect, correlative method was employed to support mimicry, without studying the impact of receiver responses on mimic fitness. While correlations do not imply causality, correlative approaches are useful for investigating putative cases of resemblance between taxa and extrapolating
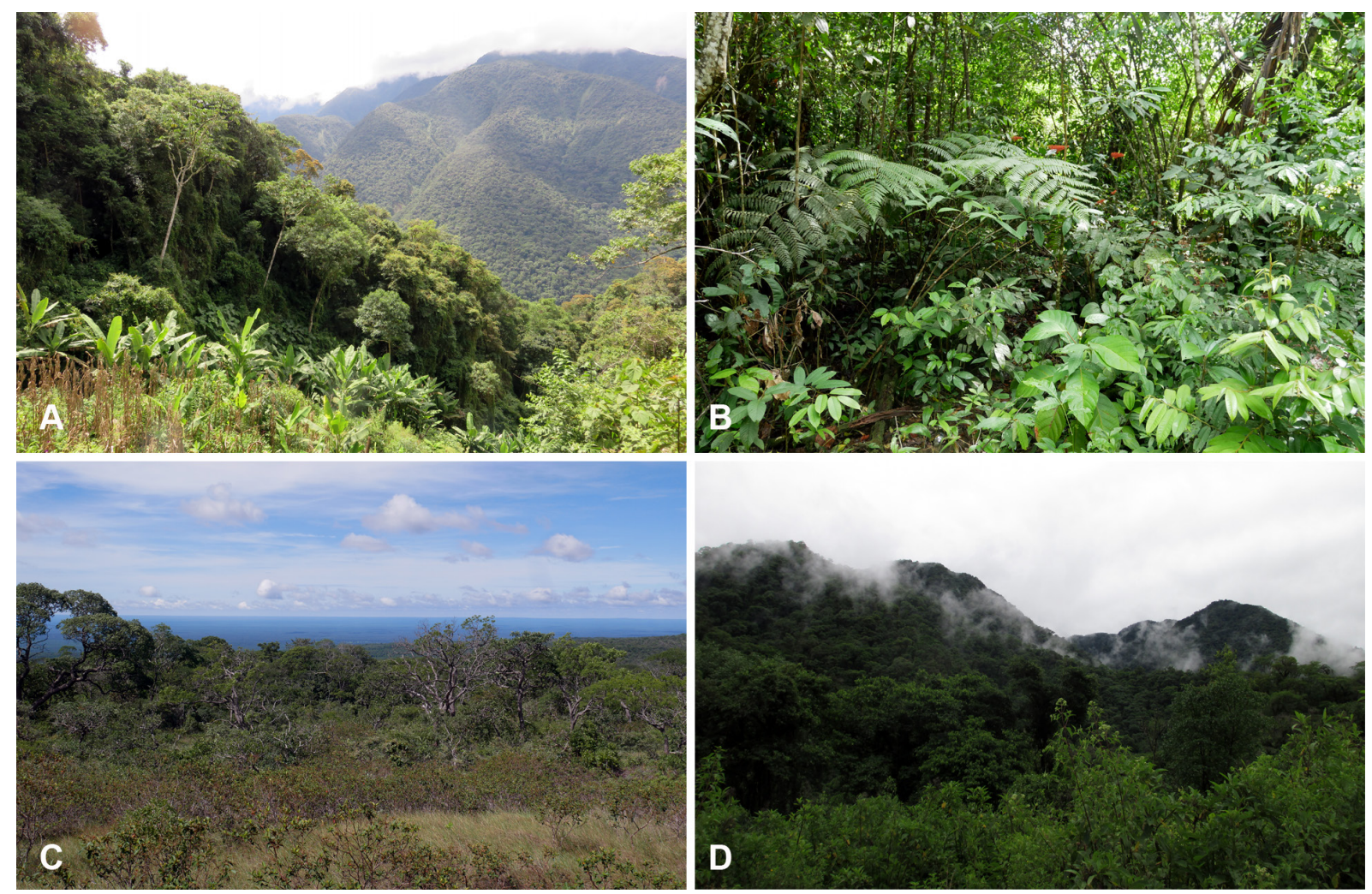

Fig. 2. Examples of sampled habitat types. A. Bolivian Yungas forest (forest edge) in Villa Teresa, La Paz Dept. B. Southwest Amazon forest (forest edge) in Villa Tunari, Cochabamba Dept. C. Cerrado savanna, Santiago de Chiquitos, Santa Cruz Dept. D. Bolivian Tucuman forest, Arambulo, Tarija Dept. 
the consequences of mimicry beyond a single, well-studied population (de Jager \& Anderson 2019). To illustrate adaptive divergence between mimetic and non-mimetic phenotypes, we identified derived traits in the mimic that likely evolved in association with species-specific models and receivers.

For the analysis of ant resemblance, we considered all ants that were collected in the surveyed locations and were about the same body length as the spiders. The similarity was analysed, based on a qualitative, descriptive assessment of integument colour, shine, development (e.g., appressed, erected, short, long) and colour of hairs and shape of body parts (e.g., abdomen shape: fusiform or ovate; apically pointed or rounded).

\section{Results}

Class Arachnida Cuvier, 1812

Order Araneae Clerck, 1757

Family Salticidae Blackwall, 1841

Tribe Simonellini Peckham, Peckham \& Wheeler, 1889

Genus Synemosyna Hentz, 1846

Synemosyna Hentz, 1846: 367.

Simonella Peckham \& Peckham, 1885: 23 (considered a junior synonym by Galiano 1966: 341).

\section{Type species}

Synemosyna formica Hentz, 1846 (by original designation).

Diagnosis (modified from Perger \& Rubio 2020a)

Species of Synemosyna can be distinguished from those of Fluda Peckham \& Peckham, 1892 and Erica Peckham \& Peckham, 1892 by a carapace laterally constricted (continuous in the latter genera) and an epigyne with a single opening (2-3 in the latter genera), and from those of Sympolymnia Perger \& Rubio, 2020 by a fusiform abdomen that is longer than the carapace, the carapace with at the most one lateral white patch, and spermathecae small, globular, pear- or kidney-shaped (abdomen ovate, carapace with 2 lateral white patches and spermathecae lung-shaped in Sympolymnia). Cylistella Simon, 1901 has a rounded, beetle-like habitus without constrictions and is the morphologically most distinct group within this tribe.

\section{Key to adults of Bolivian species of Synemosyna}

1. Constriction between cephalic and thoracic parts weakly defined laterally, only slightly narrower than both parts (Figs 3A, C, 4A, C)

- Constriction between cephalic and thoracic parts distinct laterally, considerably narrower than both parts (Figs 3B, 4B)

S. myrmeciaeformis (Taczanowski, 1871)

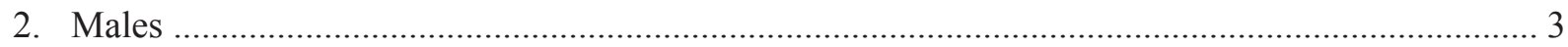

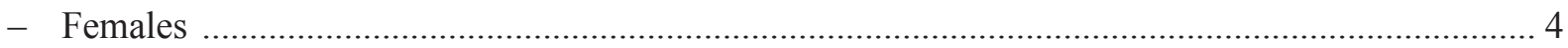

3. Tibial apophysis of male palp with obtuse dorsal tooth ............ S. aurantiaca (Mello-Leitão, 1917)

- Tibial apophysis of male palp bifurcate (Fig. 5E) ............................S. nicaraguaensis Cutler, 1993

4. Copulatory ducts entering spermathecae anteriorly, approximately four times longer than spermathecae

S. aurantiaca (Mello-Leitão, 1917)

- Copulatory ducts enter spermathecae posteriorly, approximately twice the length of spermathecae (Fig. 5D)

S. nicaraguaensis Cutler, 1993 
Synemosyna aurantiaca (Mello-Leitão, 1917)

Figs 3A, D, 4A, D, 6A-D

Simonella aurantiaca Mello-Leitão, 1917: 138.

Simonella mastigostyla Mello-Leitão, 1917: 140, fig. 2.

Simonella claustrorum Mello-Leitão, 1933: 62, pl. 1 fig. 6.

Simonella ypsilon Piza, 1937: 311, pl. 1 figs 3-4, pl. 2 fig. 5.

Simonella aurantiaca - Mello-Leitão 1933: 58, pl. 1 fig. 2.

Simonella mastigostyla - Mello-Leitão 1933: 59, pl. 1 fig. 4, pl. 2 fig. 8.

Synemosyna aurantiaca - Galiano 1966: 348, figs 8-11, 44-46, 49, 61. - Cutler \& Müller 1991: 174, figs $13-15$.

\section{Type deposit}

The types of S. aurantiaca and its synonyms were destroyed in a recent fire (World Spider Catalog 2020; A. Kury, unpublished).

\section{Diagnosis}

Tibial apophysis of male palp triangular, shark fin-like and laterally flattened; bulb narrowing distally, 1.2 times longer than wide; embolus originating prolaterally, curling around retrodistal end of cymbium, bending back sharply along dorsal cymbial surface towards base, before bending back near retrolateral edge to tip; anterior margin of epigynal atrium slightly procurved; copulatory openings located posteromedially, copulatory ducts loop anteriorly back to level of spermathecae, entering kidney-shaped spermathecae anterolaterally.

\section{Material examined}

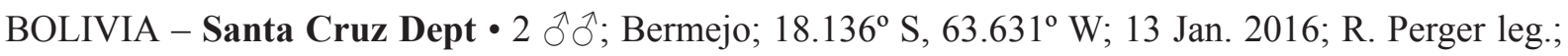

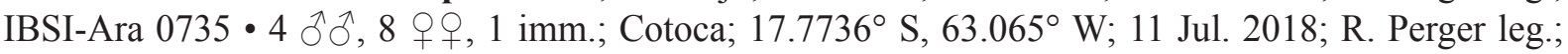

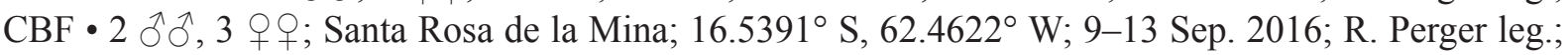
CBF. - Chuquisaca Dept 1 ภ ${ }^{\lambda}, 2$ 우; Teja Huasi; $18.9475^{\circ} \mathrm{S}, 65.1369^{\circ} \mathrm{W} ; 18$ Dec. 2017; R. Perger

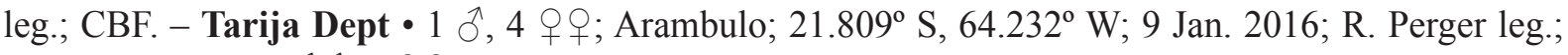
IBSI-Ara $0773 \bullet 4 \overbrace{}^{\lambda}, 5$ q $ᄋ$; same collection data as for preceding; $\mathrm{CBF}$.

ARGENTINA - Misiones Province 1 o; General Manuel Belgrano Dept, San Antonio; 26.019 S,

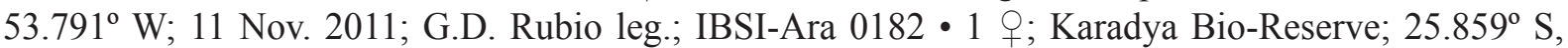
$53.961^{\circ} \mathrm{W}$; 7 Apr. 2016; J.E. Baigorria leg.; IBSI-Ara 0612 • 1 o ; same collection data as for preceding; 15 Sep. 2016; IBSI-Ara $0783 \cdot 1$ o ; Bernardo de Irigoyen; $26.247^{\circ} \mathrm{S}, 53.639^{\circ} \mathrm{W} ; 31$ Oct. 2016; G.D. Rubio leg.; IBSI-Ara 0867.

\section{Comparisons}

The triangular, shark fin-like tibial apophysis and the embolus without complete revolution are also found in S. decepiens (O. Pickard-Cambridge, 1896) (Mexico, Guatemala) (Cutler 1985). However, in the latter, the bulb broadens distally and is 1.5 times longer than wide. In S. invemar Cutler \& Müller, 1991 (Colombia), the spermathecae are kidney-shaped but the tubes do not loop back to the level of the spermathecae and enter the spermathecae posteriorly (Cutler \& Müller 1991).

\section{Variation}

The following forms were collected in sympatry in all locations: orange-reddish, light brown, and dark brown to blackish forms (Fig. 6A-D). All orange-reddish forms were smaller than $5.55 \mathrm{~mm}(\mathrm{n}=9)$ and 
all dark-brown to blackish variants longer than $5.8 \mathrm{~mm}(\mathrm{n}=8)$, indicating an ontogenetic change in body color with light brown transitional forms. There was no apparent sex-related difference in body color.

\section{Geographical and ecoregion distribution (Fig. 7)}

This species has been recorded from Brazil (Galiano 1966; Raizer 2004; Podgaiski et al. 2007; Rodrigues et al. 2009, 2016), Uruguay (Laborda Turrión 2016), Argentina (Galiano 1966; Zapata \& Grismado 2015) and Bolivia (present study). Cutler \& Edwards (2002) recorded S. aurantiaca from Trinidad Island (Lesser Antilles). The taxonomic status of these specimens remains to be determined. Synemosyna aurantiaca is distributed in mostly semi-deciduous forests south of $18^{\circ}$ (Fig. 7). According to the biogeographic regionalization of Olson et al. (2011), previous records refer to the following ecoregions: Pantanal, Humid Pampas, Parana flooded Savanna, Uruguayan Savanna, Alto Paraná Atlantic forest, Serra do Mar coastal forests and Araucaria moist forest. In the present study, S. aurantiaca was sampled in Inter-Andean Bolivian Tucuman dry forest (Teja Huasi), Bolivian Tucuman forests (Arambulo), and subhumid, semi-deciduous Chiquitano forest (Bermejo, Cotoca, Santa Rosa de la Mina, Santiago de Chiquitos).

\section{Remarks}

Galiano (1966) collected co-occurring yellow/orange and dark forms in Paraná de las Palmas and Canal 6, Buenos Aires province, Argentina. Oliveira (1988) reported similar forms from Brazil. Both authors mentioned that the species lacks sexual dichromatism, which is supported by the observations in the present study.

Previous records of this species referred to a comparably narrow range in southeast Brazil and northeast Argentina. Synemosyna aurantiaca is reported here for the first time from Bolivia. Teja

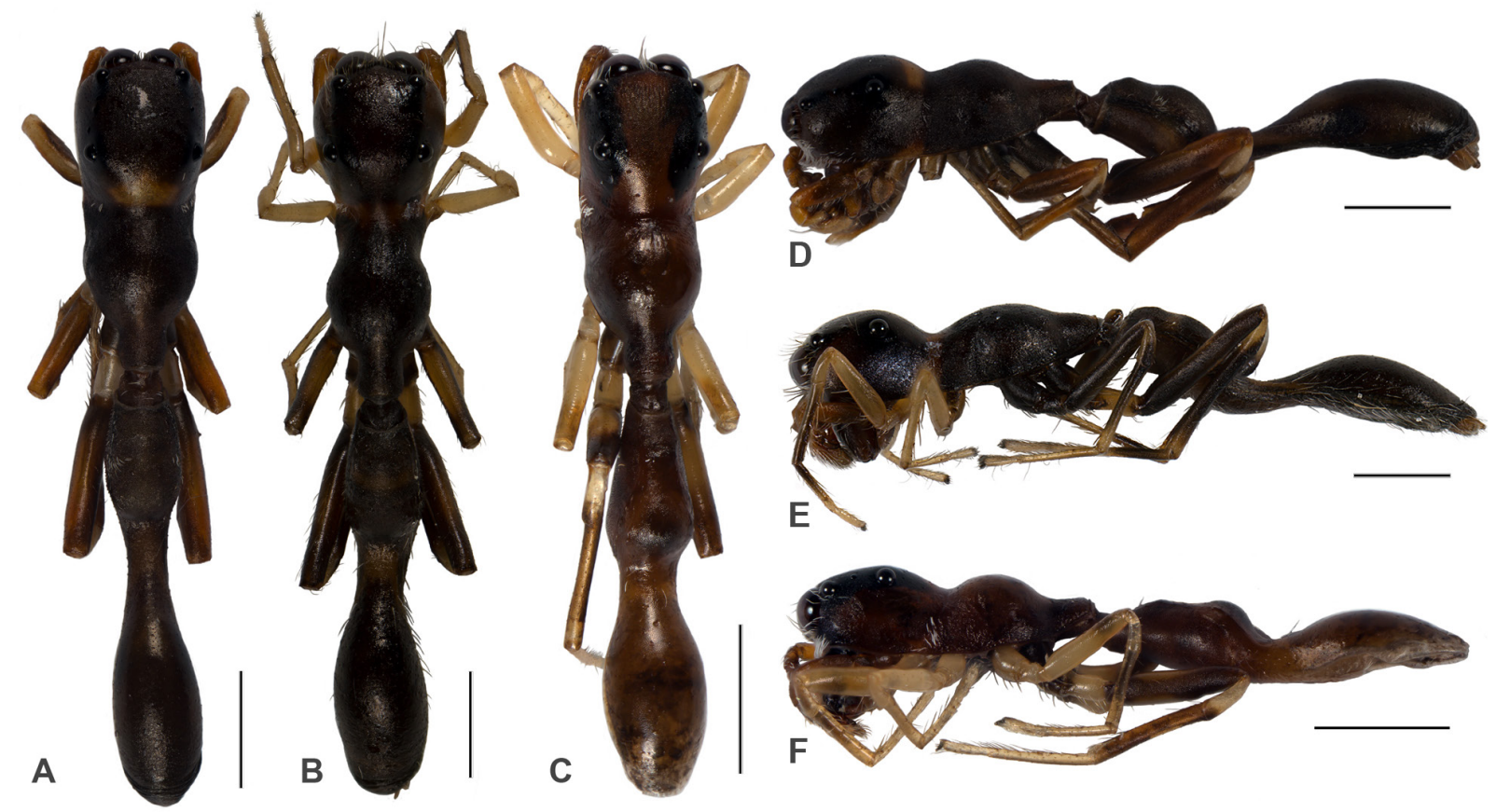

Fig. 3. Dorsal and lateral habitus, males (all CBF). A, D. Synemosyna aurantiaca (Mello-Leitão, 1917). B, E. S. myrmeciaeformis (Taczanowski, 1871). C, F. S. nicaraguaensis Cutler, 1993. Scale bars = $1 \mathrm{~mm}$. 
Huasi (Chuquisaca Dept), located at an elevation of $2000 \mathrm{~m}$ a.s.1., is the highest reported elevation for any species of the tribe Simonellini. The record from Bermejo (Santa Cruz Dept) is the northernand westernmost record of this species, extending the distributional range more than $900 \mathrm{~km}$ to the northwest of the previously reported northernmost location in Mato Grosso do Sul (Fazenda São Bento, Brazil).

The record from Colombia (Cutler \& Müller 1991) likely refers to another species, as the illustrated female does not only have a different epigyne (as already stated by Cutler \& Müller 1991), but also pear-shaped spermathecae (kidney-shaped in $S$. aurantiaca); a bipartite dorsal scutum on the anterior half of the abdomen (one entire scutum in $S$. aurantiaca); a narrower carapace, resulting in a ratio length/width of 2.7 ( $\sim 2.1$ in $S$. aurantiaca), with concave lateral borders (convex in $S$. aurantiaca), and the middle part as narrow as the distance between the last posterior eyes (broader in S. aurantiaca).

\section{Synemosyna myrmeciaeformis (Taczanowski, 1871)}

Figs 3B, E, 4B, E, 5A-B, 8A-D

Janus myrmeciaeformis Taczanowski, 1871: 125, pl. 4 fig. 9.

Simonella peckhami Mello-Leitão, 1933: 56.

Simonella myrmeciaeformis - Peckham et al. 1889: 253, pl. 12 fig. 8. — Peckham \& Peckham 1892: 81, pl. 7 fig. 4. - Simon 1901: 509, figs 605-609.

Synemosyna myrmeciformis - Galiano 1966: 367, figs 18-20, 38-39.

\section{Type deposit}

Holotype $\delta$ in PAS; Janus myrmeciaeformis Taczanowski, 1871 (examined).
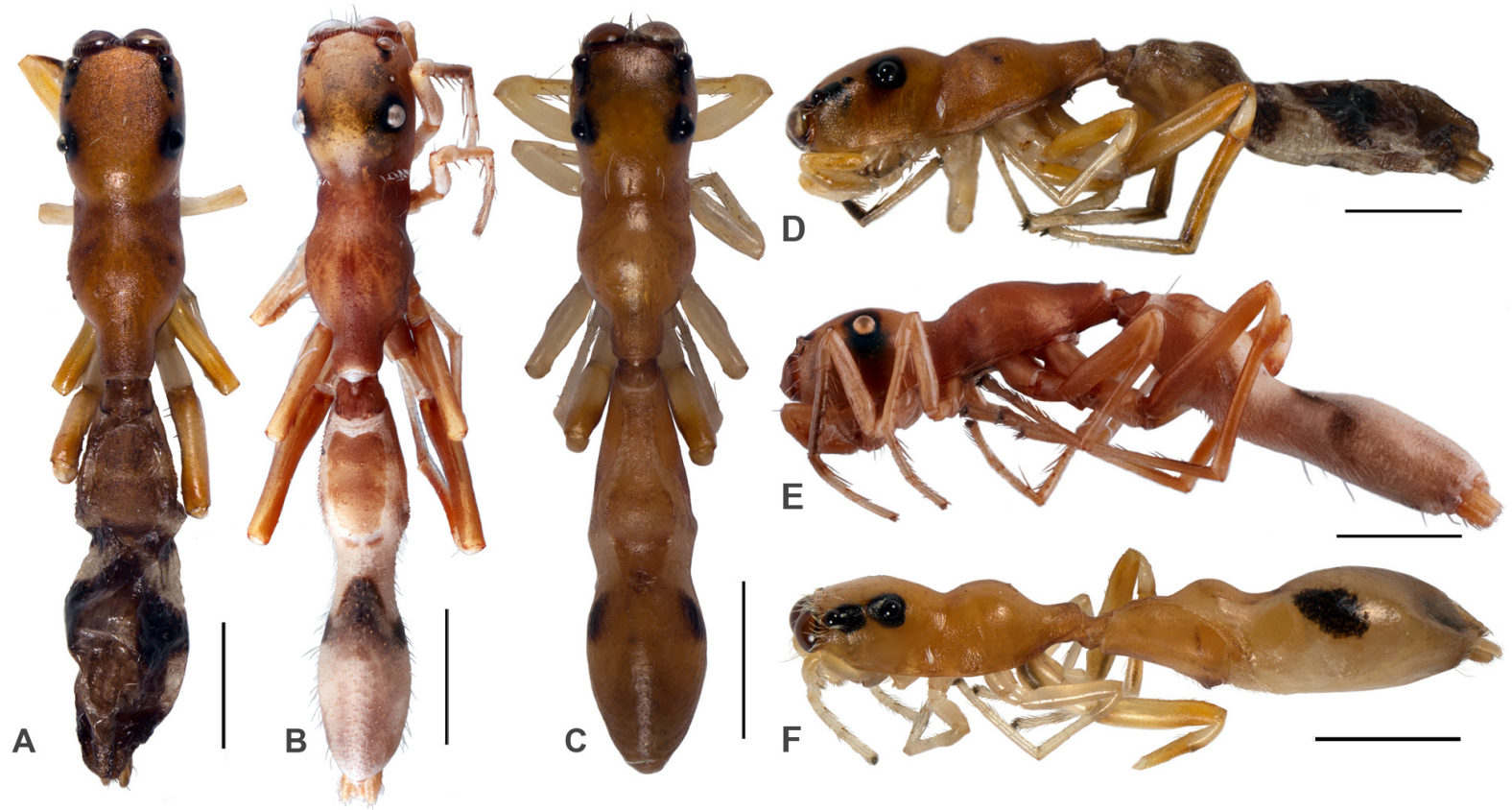

Fig. 4. Dorsal and lateral habitus, females (all CBF). A, D. Synemosyna aurantiaca (Mello-Leitão, 1917). B, E. S. myrmeciaeformis (Taczanowski, 1871). C, F. S. nicaraguaensis Cutler, 1993. Scale bars $=1 \mathrm{~mm}$. 


\section{Diagnosis}

Tibial apophysis of male palp finger-like, with distinct median bend, somewhat laterally flattened; bulb large, obliquely oval, $70 \%$ of cymbium length; embolus originating prolaterally, with complete revolution around bulb, tip directed retrodistally; epigyne with transverse atrium with subtriangular excavation anteriorly (Fig. 5A); copulatory openings located posterolaterally in atrium, copulatory ducts directed anteriorly, with S-shaped loop at level of spermathecae, entering globular spermathecae posteriorly (Fig. 5B),

\section{Material examined}

\section{Holotype}

FRENCH GUIANA • ̊̂; Saint Laurent du Maroni; R. Jelski leg.; PAS.

\section{Other material}

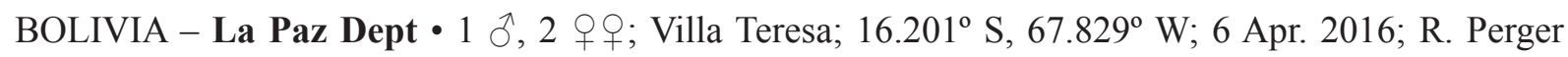
leg.; IBSI-Ara $0756 \cdot 3$ ô; same collection data as for preceding; 17 Jan. 2018; R. Perger leg.; IBSIAra 1022 • 2 กํ, 6 우, 1 imm.; same collection data as for preceding; CBF. - Cochabamba Dept •

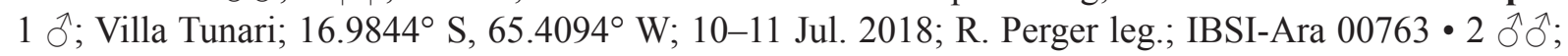
same collection data as for preceding; 6 Dec. 2017; R. Perger leg.; IBSI-Ara 1032 • 1 ô, 6 q $q$; same collection data as for preceding; CBF. - Beni Dept • 3 ते ô, 9 q $q$; Riberalta; $11.0163^{\circ} \mathrm{S}, 65.9958^{\circ} \mathrm{W}$; 21-23 Jan. 2018; R. Perger leg.; CBF.

\section{Comparisons}

The shape of the tibial apophysis and the embolus with complete circular revolution are shared with S. americana (Peckham \& Peckham, 1885) (Mexico to Venezuela) and S. petrunkevichi (Chapin, 1922) (USA, Cuba). However, both species can be separated by a smaller bulb (65\% of cymbium length in S. americana and $50 \%$ in S. petrunkevichi). In addition to differences in genitalic characters, S. americana and $S$. petrunkevichi have the carapace not or only slightly narrowed between the cephalic and thoracic areas.

The carapace narrowed between cephalic and thoracic areas, and the globular and small spermathecae of S. myrmeciaeformis, are shared with S. paraenesis Galiano, 1967 (Brazil, French Guiana). Females of the latter can be distinguished from those of $S$. myrmeciaeformis by the spermathecae located in a protuberance in the epigastric area and the copulatory ducts entering the spermathecae laterally, while entering the spermathecae posteriorly in S. myrmeciaeformis (Fig. 5B). Additionally, the tibial apophysis of the male palp of $S$. paraensis is bifurcate.

\section{Variation}

Three different color forms were observed, displaying a different geographic pattern: orange (in all three locations) (Fig. 8A), orange forms with black cephalic part (Villa Tunari, Cochabamba Dept, and Riberalta, Beni Dept) (Fig. 8B), or dark brown (Villa Teresa, La Paz Dept) forms (Fig. 8C-D). There was no apparent sex-related difference in body color. However, there may be an ontogenetic change in body color. Orange variants were observed within a generally smaller size range of 3.1-6.7 mm $(\mathrm{n}=11)$, dark brown individuals in a range of $6.3-8.05 \mathrm{~mm}(\mathrm{n}=10)$, and orange forms with a black cephalic part in a range of 5.84-8.00 $\mathrm{mm}(\mathrm{n}=20)$. The dark brown and orange forms with black cephalic part are described here for the first time.

\section{Geographical and ecoregion distribution (Fig. 7)}

Synemosyna myrmeciaeformis is known from Venezuela (type locality), French Guiana, Brazil (Peckham \& Peckham 1892; Galiano 1966) and Bolivia (Cutler 1981a; present study). This species 
was found in ecoregions of the Amazon biome north of $16^{\circ} \mathrm{S}$ (Fig. 7). The distributional data of S. myrmeciaeformis refers to Cordillera La Costa montane forest, Guianan moist forest, and UatumaTrombetas moist forest (ecoregion regionalization according to Olson et al. 2011). In the present study, the species was collected in Sub-Andean Southwest Amazon forest (Villa Tunari, Riberalta) and Bolivian Yungas forest (Villa Teresa).

\section{Remarks}

Taczanowski (1871) described S. myrmeciaeformis based on a male. Peckham \& Peckham (1892) described the female, although Galiano (1966) mentioned that no female could be found among the material examined by Peckham \& Peckham (1892). Cutler \& Müller (1991) stated that the female of S. myrmeciaeformis was still considered to be unknown. The females collected in the current study are consistent with the description of Peckham \& Peckham (1892), which we here consider to be valid. The female is illustrated here for the first time (Figs 4B, E, 5A-B, 8A-C). With a maximum BL of $8.05 \mathrm{~mm}$, S. myrmeciaeformis is the largest Bolivian species of Synemosyna collected in this study (maximum BL of S. aurantiaca $7.0 \mathrm{~mm}$ and of S. nicaraguaensis $5.85 \mathrm{~mm}$ ).

\section{Synemosyna nicaraguaensis Cutler, 1993}

Figs 3C, F, 4C, F, 5C-F, 9A-D

Synemosyna nicaraguaensis Cutler, 1993: 2, figs 1-2.

\section{Type deposit}

Holotype $q$ in MEL (examined).
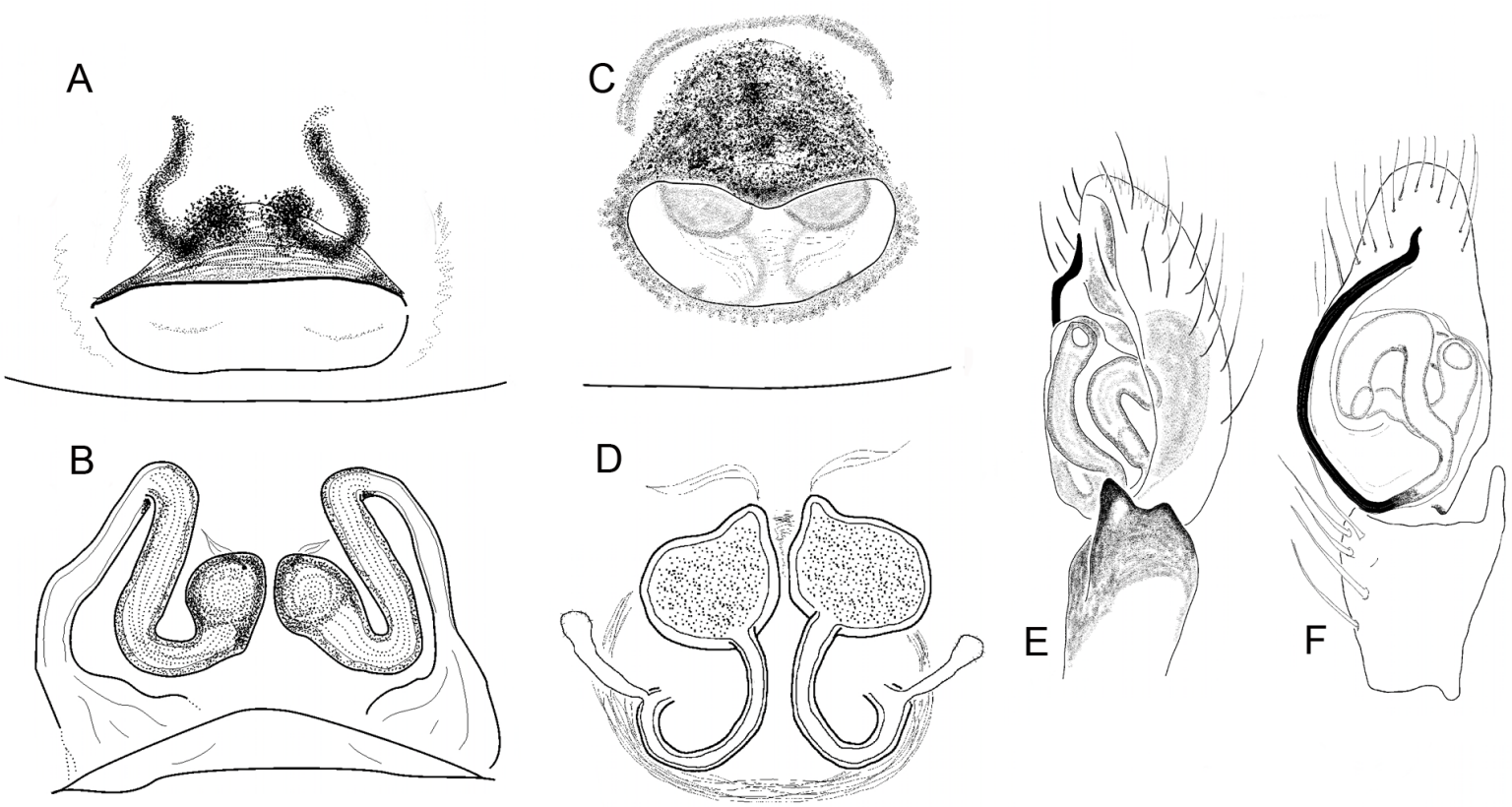

Fig. 5. Genitalia of Synemosyna spp. A-B. S. myrmeciaeformis (Taczanowski, 1871). A. Epigyne. B. Spermatheca and copulatory duct. C-F. S. nicaraguaensis Cutler, 1993. C. Epigyne. D. Spermatheca and copulatory duct. E. Palp, retrolateral view. F. Idem, ventral view. 


\section{Diagnosis}

Bulb small (60\% of cymbium length) (Fig. 5F); tibial apophysis bifurcate, ventral lobe larger; epigyne with complete, sclerotized transverse hood with strongly procurved anterior margin; female spermathecae large (width of each 35-45\% of maximum width of epigyne between sclerotized rims), pear-shaped, and accessory glands as long as spermatheca diameter (Fig. 5D).

\section{Material examined}

\section{Holotype}

NICARAGUA - +; Río San Juan, El Castillo [El Castillo de Concepción, $11^{\circ} 01^{\prime}$ N, 8425’ W]; 30 Jul. 1989; F. Reinboldt leg.; MEL.

\section{Other material}

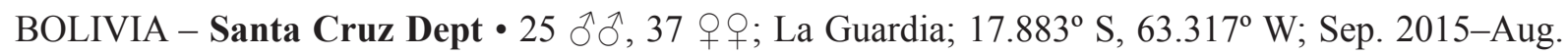

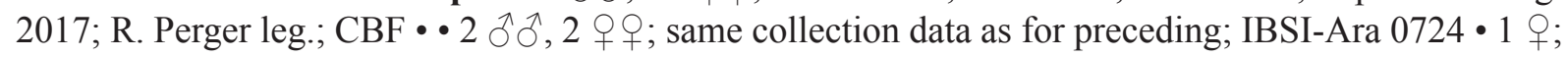
Buena Vista; $17.465^{\circ}$ S, $63.696^{\circ}$ W; 21 Jan. 2016; R. Perger leg.; IBSI-Ara $0725 \bullet 2$ q $q$; same collection

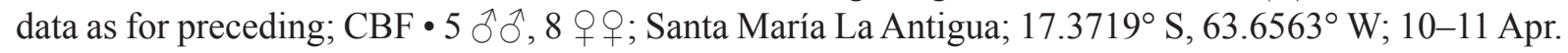

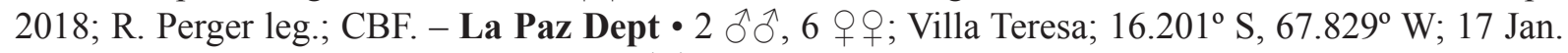

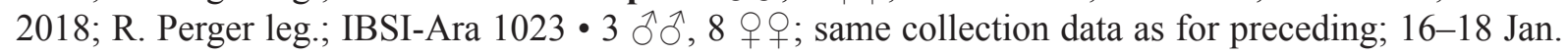
2018; R. Perger leg.; CBF.

\section{Comparisons}

The bifurcated tibial apophysis is only shared with S. maddisoni Cutler, 1985 and S. paraensis Galiano, 1967. However, both species can be separated from $S$. nicaraguaensis by a larger bulb (65\% of cymbium length in $S$. maddisoni and $80 \%$ in $S$. paraensis) and the different size and shape of the lobes of the retrolateral tibial apophysis (cf. Fig. 5F with Chamé-Vázquez et al. 2020: figs 14-15). The female habitus (Fig. 4C) and the almost round spermathecae (Fig. 5D) are shared with the female of S. maddisoni. Females of $S$. maddisoni can be distinguished from those of S. nicaraguaensis by an epigyne with a U-shaped flap, which is wide and short in S. nicaraguaensis (compare Fig. 5C with Chamé-Vázquez et al. 2020: fig. 11).

The habitus of females of $S$. nicaraguaensis resembles that of $S$. hentzi Peckham \& Peckham, 1892 (Peckham \& Peckham 1892: pl. 7 fig. 2). Synemosyna hentzi was described very briefly based on a single female that was collected in Chapada dos Guimarães, close to Cuiabá, Mato Grosso state, Brazil, and maintained in the Herbert H. Smith collection (Peckham \& Peckham 1892), but the type specimen appears to be lost (Galiano 1971). No description or illustration of the genitalia was provided, and no further specimens of this species were recorded in subsequent works. Considering the original description (Peckham \& Peckham 1892), S. hentzi differs from S. nicaraguaensis by a broader, less elongated carapace, 2 times longer than wide ( 2.5 in $S$. nicaraguaensis), with the lateral borders parallel (with a slightly narrower constriction in S. nicaraguaensis) and without a dorsal constriction (present in S. nicaraguaensis), the AER only slightly curved (strongly in S. nicaraguaensis), and the ALE and AME touching each other (separated in S. nicaraguaensis).

\section{Description}

Male (IBSI-Ara 0724)

Total BL: 4.60. Carapace length 2.05; width: 0.81. Integument smooth, shiny, with simple, separate white setae, denser and longer on cephalic area (particularly around AME), posterior constriction of thoracic area, and on transverse area of anterior part of abdomen. Carapace slender and elongated, cephalic portion slightly longer than wide, followed by slightly narrower constriction, slight impression behind cephalic area (resembling anterior pronotal margin); dense white scales posterolateral of cephalic area, thoracic part about as long as cephalic part, of same width, globose, posteriorly constricted, constriction 
concave in lateral view. Row of AME and ALE recurved, AME touching each other, separated from ALE, ALE at anterior edges of cephalic area, rectangle of ALE and PE 1.5 times as wide as long. Chelicerae with 2 promarginal and 5 retromarginal teeth. Sternum dark brown. Coxae and trochanters translucent whitish; legs relatively long, 4312; femora stout, remaining segments slender, femora I-III translucent yellowish, I and III somewhat darker distally, IV proximally and distally as in anterior part of abdomen, central half translucent yellowish; tibia I simple, with moderately long setae.

Abdomen length: 2.50; width: 0.70, proximal half broadening in distal direction in dorsal view, proximal and distal half of abdomen separated by concave constriction, distal part of abdomen acuminate oval. Dorsal scutum almost extending along the whole length of abdomen, rectangular proximally, merging into disc-shaped, heavily sclerotized plate on distal half of anterior abdominal part, proximal part of plate surrounded by band of short white setae; scutum narrowing at level of abdominal constriction and
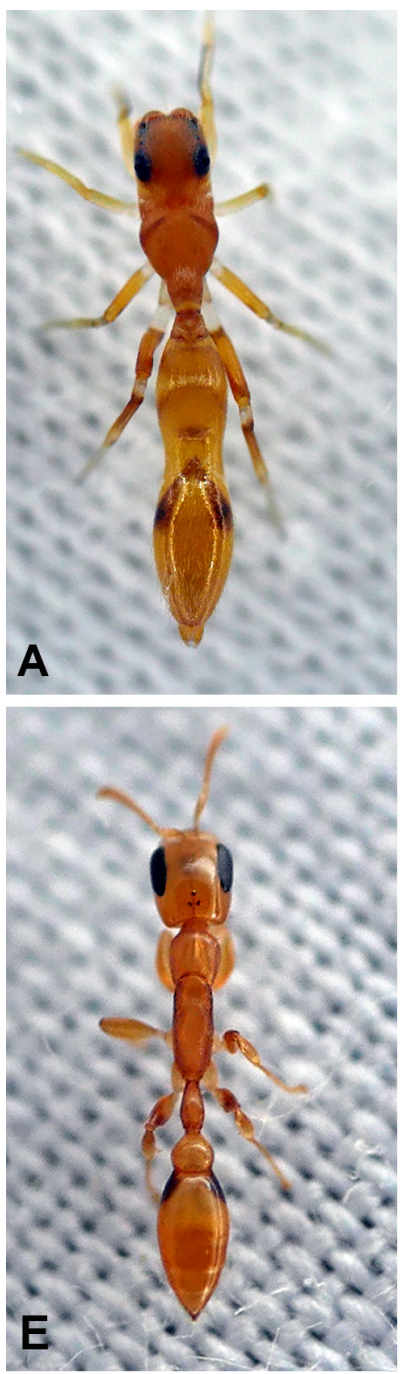
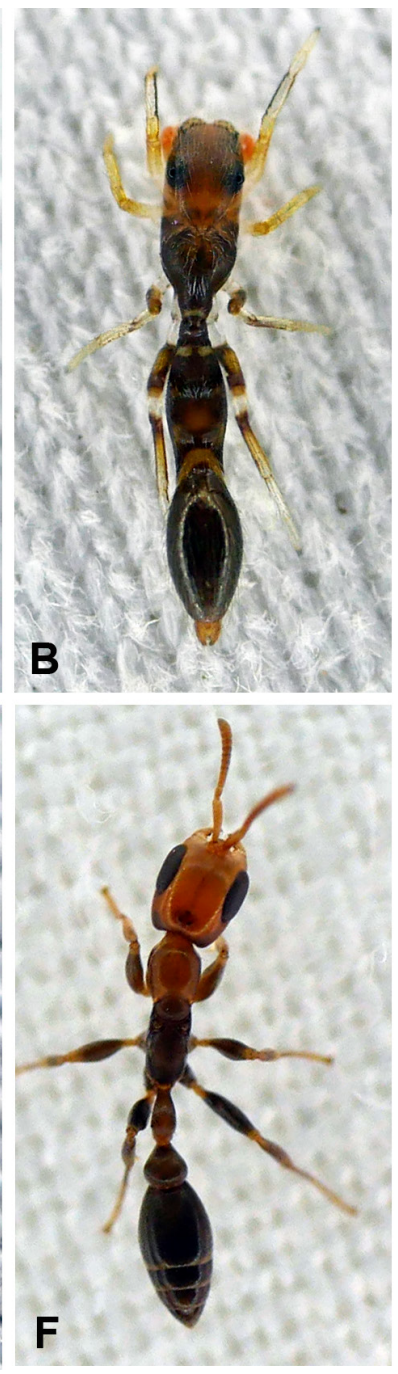
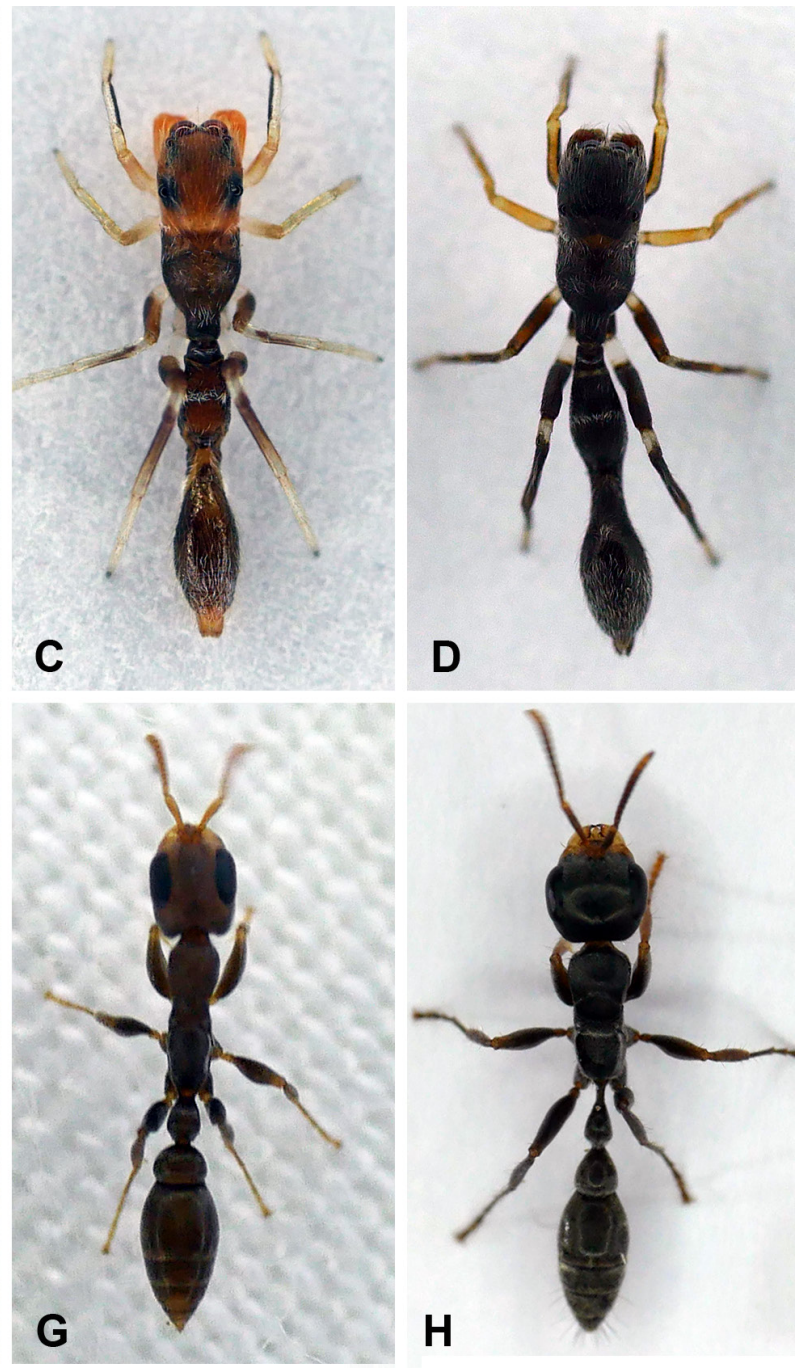

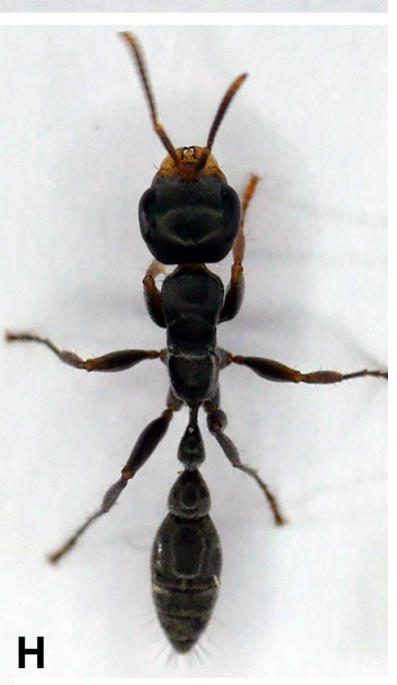

Fig. 6. A-D. Color variants and potential model ants for Synemosyna aurantiaca (Mello-Leitão, 1917). A. Orange female, Santiago de Chiquitos, Santa Cruz Dept. B. Reddish brown female, Cotoca, Santa Cruz Dept. C. Reddish brown male, Bermejo, Santa Cruz Dept. D. Dark brown male, Arambulo, Tarija Dept. E. Pseudomyrmex simplex (Smith, 1877). F. P. filiformis (Fabricius, 1804). G. P. elongatus (Mayr, 1870). H. P. gracilis (Fabricius, 1804). 
widening again on distal half of abdomen, terminating shortly before abdominal apex; epigastric scutum folded over dorsolateral border of anterior part of abdomen, covering somewhat lateral sides of scutum.

Bulb about $60 \%$ of the cymbium length, ovoid, narrowing proximally, tibial apophysis bifurcate, ventral tooth larger; embolus thin, arising from the basal side of the bulb, without complete circular revolution, angular, surrounding bulb prolaterally towards the apical cymbial groove.

\section{Variation}

Four different color morphs were observed in males (Fig. 9B-D, Table 1), with no apparent ontogenetic change in body color. The forms included orange-reddish, completely light brown or dark brown forms (all locations), and variants with dark orange carapace and black abdomen (La Guardia and Villa Teresa). In a sample of 51 females, $92 \%$ were orange with a pair of black spots on the posterior half of the abdomen (Fig. 9A), and 8\% dark brown. Orange males with dark spots on their abdomen were not observed. The comparably even distribution of color forms among males, the high number of orange females, and the lack of orange forms with black abdominal spots in males indicate sex-specific polychromatism.

\section{Geographical and ecoregion distribution (Fig. 7)}

Synemosyna nicaraguaensis is known from Nicaragua (type location) and Bolivia (present study). In Bolivia, it was collected in the following forest types: Bolivian Yungas forest (Villa Teresa), Sub-Andean Southwest Amazon moist forest (Buena Vista), and Sub-Andean subhumid semi-deciduous Chiquitano forest (La Guardia, Santa María la Antigua).

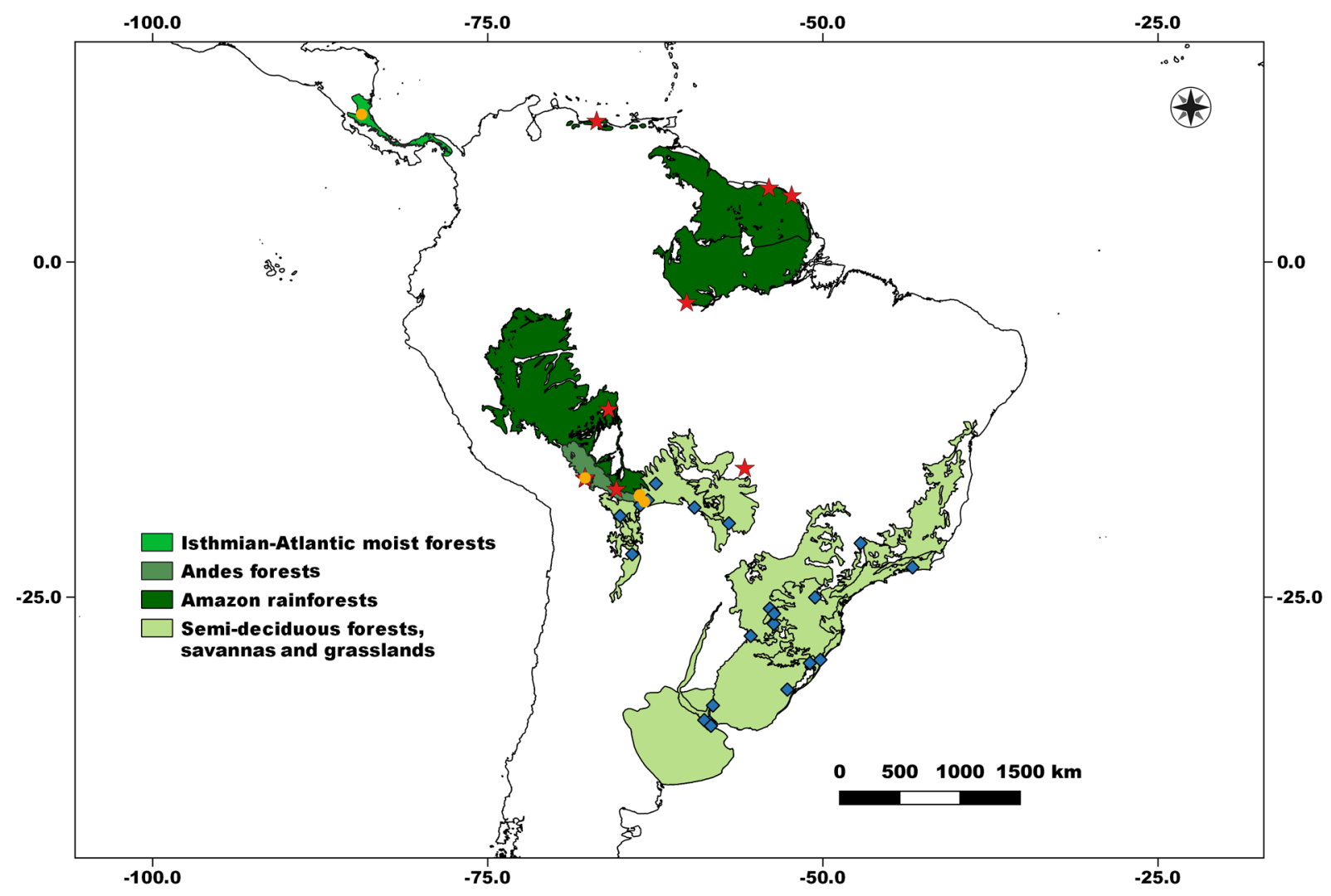

Fig. 7. Ecoregion distribution of Synemosyna spp. Orange circle = S. nicaraguaensis Cutler, 1993; red star $=$ S. myrmeciaeformis $($ Taczanowski, 1871); blue diamond $=$ S. aurantiaca (Mello-Leitão, 1917). 
Table 1. Co-occurrence pattern of Bolivian Synemosyna Hentz, 1846 species and potential model species of Pseudomyrmex Lund, 1831 (only localities with a sample size higher than $\mathrm{n}=12$ were considered): S. aurantiaca (Mello-Leitão, 1917) (I) 2.5-5.5 mm (orange-reddish); (II) 4.6-6.4 mm (light brown); (III) 5.8-7.0 mm (dark brown/blackish); S. myrmeciaeformis (Taczanowski, 1871) (I) 3.1-6.7 mm (orange); (II) 6.0-8.0 mm (dark brown or orange with black cephalic part); S. nicaraguaensis Cutler, 1993 (I) male 2.65-5.85 mm (orange-reddish); (II) male 3.45-5.85 mm (brownish); (III) male 3.84-5.05 mm (orange carapace and blackish abdomen); (IV) female 3.45-5.2 mm (orange). Abbreviations: A = Arambulo; $\mathrm{C}=$ Cotoca; $\mathrm{L}=\mathrm{La}$ Guardia; $\mathrm{S}=$ Santa María La Antigua; $\mathrm{V}=$ Villa Tunari; VT = Villa Teresa. Please note that orange and brown forms of Pseudomyrmex triplarinus (Weddell, 1850) were observed. Body length of Pseudomyrmex spp.: P. simplex (Smith, 1877) BL 3.7-4.5 mm; P. cf. pallidus (Smith, 1855) BL 3.3-3.95 mm; P. triplarinus (Weddell, 1850) (BL 4.8-6.7 mm); P. sericeus (Mayr, 1870) BL 4.4$5.05 \mathrm{~mm}$; P. elongatus (Mayr, 1870) BL 2.9-3.8 mm; P. phyllophilus (Smith, 1858) BL 4.9-5.1 mm; $P$. cf. filiformis (Fabricius, 1804) BL 4.6-5.2 mm; P. peruvianus (Wheeler, 1925) (BL 3.0-3.5 mm); P. gracilis (Fabricius, 1804) BL 6.7-11.0 mm; P. tenuis (Fabricius, 1804) BL 5.3-7.0 mm.

\begin{tabular}{|c|c|c|c|c|c|c|c|c|c|}
\hline \multirow[b]{2}{*}{ Potential ant model } & \multicolumn{3}{|c|}{ S. aurantiaca } & \multicolumn{2}{|c|}{ S. myrmeciaeformis } & \multicolumn{4}{|c|}{ S. nicaraguaensis } \\
\hline & I & II & III & I & II & I & II & III & IV \\
\hline \multicolumn{10}{|l|}{ Orange forms } \\
\hline P. simplex (Smith, 1877) & $\mathrm{A}, \mathrm{C}$ & & & VT, R, V & & & & & L, VT, S \\
\hline P. cf. pallidus (Smith, 1855) & & & & & & $\mathrm{L}, \mathrm{VT}, \mathrm{S}$ & & & \\
\hline P. triplarinus (Weddell, 1850) & & & & & & $\mathrm{L}, \mathrm{S}$ & & & \\
\hline \multicolumn{10}{|l|}{ Brownish forms } \\
\hline P. sericeus (Mayr, 1870) & & & & & & & $\mathrm{L}, \mathrm{VT}, \mathrm{S}$ & & \\
\hline P. elongatus (Mayr, 1870) & & $\mathrm{A}, \mathrm{C}$ & & & & & $\mathrm{L}, \mathrm{VT}, \mathrm{S}$ & & \\
\hline P. phyllophilus (Smith, 1858) & & $\mathrm{A}, \mathrm{C}$ & & & & & $\mathrm{L}$ & & \\
\hline P. cf. filiformis (Fabricius, 1804) & & $\mathrm{A}, \mathrm{C}$ & & & & & & L, VT & \\
\hline P. peruvianus (Wheeler, 1925) & & & & & & & & VT & \\
\hline P. triplarinus (Weddell, 1850) & & & & & VT & & VT & & \\
\hline P. gracilis (Fabricius, 1804) & & & $\mathrm{A}, \mathrm{C}$ & & VT & & & & \\
\hline \multicolumn{10}{|l|}{ Orange body/black head } \\
\hline P. tenuis (Fabricius, 1804) & & & & & $\mathrm{R}, \mathrm{V}$ & & & & \\
\hline
\end{tabular}

\section{Remarks}

The localities in Nicaragua and Bolivia are more than $3500 \mathrm{~km}$ apart, which is remarkable for such a small arthropod, and would suggest a certain degree of reproductive isolation between both populations. However, the epigyne (examined from drawings by Cutler 1993) and external morphology (examined from photographs of the type) are similar in the type specimen of S. nicaraguaensis and the Bolivian material. Another species with a wide distributional range, S. americana, occurs from Mexico to Venezuela (Cutler 1981b). The other two Bolivian species of Synemosyna have also comparably wide distribution ranges (Fig. 7). The widest collection locations of $S$. aurantiaca are about $2200 \mathrm{~km}$ apart, and of $S$. myrmeciaeformis about $3100 \mathrm{~km}$. Molecular studies are needed to test whether the low grade of morphological differentiation in these species represents a high gene flow.

\section{Discussion}

In this study, the presence of previously unrecorded species of Synemosyna from Bolivia was not surprising, as the spider fauna of the country is generally poorly known (Cutler 1981a; Perger \& Rubio 2018, 2020a, 2020b). The Synemosyna fauna of Tucuman and Chiquitano forests was completely unknown, 
which is consistent with the sampling effort reported for other invertebrate groups (Perger \& Grossi 2013; Perger 2015).

With three species, Bolivia harbors as many species of Synemosyna as Mexico, and is only exceeded by Brazil (six spp.) and Colombia (four spp.). The turnover of Synemosyna spp. appears to be consistent with the delineation of moist tropical Amazon forests and semideciduous forests (including Chiquitano forest, Bolivian Tucuman forest, Cerrado, and Atlantic forest) (Fig. 7). Synemosyna myrmeciaeformis was recorded from Bolivian Yungas forest and ecoregions of the Amazon biome north of $16^{\circ} \mathrm{S}$, while S. aurantiaca is distributed in semi-deciduous forests south of $18^{\circ}$. The presence of $S$. nicaraguaensis in Sub-Andean and Andean forests and Nicaragua suggests that this species is typical for the Northern Tropical Andes fauna.

This pattern suggests that the significant shift in seasonality and related conditions triggered speciation in Synemosyna. For example, the Chiquitano forest ecoregion is distinguished by a pronounced seasonality and lower annual precipitation than Amazon forests (Ibisch \& Mérida 2003). Ecological speciation has also been invoked to explain high species richness in the Simonellini genus Sympolymnia Perger \& Rubio, 2020 (Perger \& Rubio 2020a), Castianeirinae Reiskind, 1969 spiders (Perger \& Perger 2017), and several insect groups (Pearson et al. 1999; Wappes et al. 2011). Nevertheless, it is likely that the comparably high richness of Bolivian species of Synemosyna is partly explained by low sampling effort in Brazil, Ecuador, Peru, and Venezuela.

In any case, the low grade of morphological differentiation of the species of Synemosyna, reflected by their wide distributional ranges, contrasts with the ecosystem specificity that was observed in other arthropods (e.g., Pearson et al. 1999; Wappes et al. 2011), and explains the low species richness of this genus at a continental scale. Further sampling campaigns in undersampled microhabitats and poorly sampled vegetation types, and molecular analyses, are needed to clarify the biogeographical relationships of Synemosyna.

\section{Ant mimicry}

Strong indirect support for ant mimicry was provided by: 1) species-specific similarity involving morphological aspects, including resembling polychromatic forms (Figs 6, 8-9);2) sympatry: both model ants and mimicking spiders were found in the same habitats (Table 1), and mimics were less abundant than the models. Alternative processes, such as convergent evolution, exploitation of perceptual bias, developmental or phylogenetic constraints, spatial autocorrelation, crypsis, or random matching (de Jager \& Anderson 2019) were unlikely to be responsible for the resemblance between ants and spiders in the present case.

The most remarkable observation was the co-occurrence of Pseudomyrmex tenuis (Fabricius, 1804) and adults of S. myrmeciaeformis with an orange body and blackish cephalic area (both exclusively observed in Villa Tunari and Riberalta). Pseudomyrmex tenuis was the only species of Pseudomyrmex with an orange body and black head that was observed in the study area. It was absent in Villa Teresa, where only dark brown adults of $S$. myrmeciaeformis were observed, which mimic P. triplarinus (Weddell, 1850) or P. gracilis (Fabricius, 1804).

The high polymorphism in males of $S$. nicaraguaensis was consistent with the presence of 2 to 6 small to medium-sized species of Pseudomyrmex with a similar body color (Table 1). In contrast, $95 \%$ of the females of $S$. nicaraguaensis $(\mathrm{n}=39)$ resembled P. simplex (Smith, 1877), which have an orange body with black spots on their gaster (spots absent in males of $S$. nicaraguaensis). Brown forms of S. nicaraguaensis were lighter and smaller (max. BL $5.85 \mathrm{~mm}$ ) than the dark-brown/blackish $P$. gracilis (the largest Pseudomyrmex spp., BL 6.7-11.0 mm). 
Species of Synemosyna are commonly cited examples for ant mimicry because of their close resemblance to species of Pseudomyrmex (reviewed by Cushing 1997). However, the elongated body of Pseudomyrmex with comparably short legs, large eyes, and their movement with short, rapid lunges, is rather unusual for ants - the name Pseudomyrmex translates as "false ant" (Deyrup 2016). Because the general habitus of Pseudomyrmex considerably varies from that of most ants and the habitus of Synemosyna from most spiders (including ant-resembling forms), the morphological similarity between Pseudomyrmex and Synemosyna spp. provides strong indirect evidence for mimicry. For example, the globose abdomen, less elongated carapace, and long legs in myrmecomorphic sac spiders of the genus Myrmecotypus O. Pickard-Cambridge, 1894 appears to be more spider-like (see Perger \& Rubio 2020b).

The resemblance between models and spiders is additionally increased by a deep constriction in the spider's abdomen, which imitates the separation between the postpetiole and the gaster of the ants (the anterior part of the abdomen imitates the petiole and postpetiole, not only the postpetiole, as stated
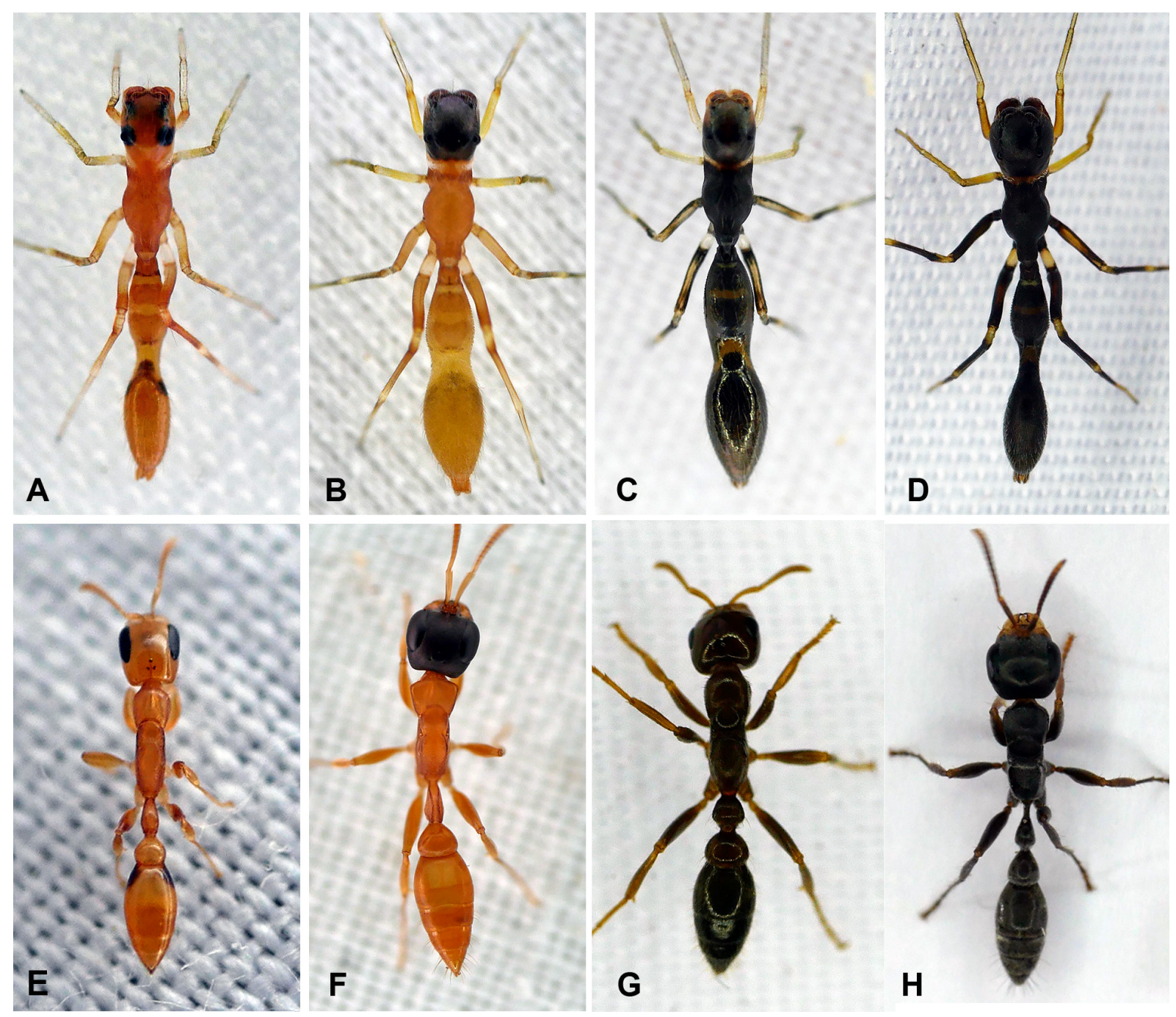

Fig. 8. A-D. Color variants and potential model ants for Synemosyna myrmeciaeformis (Taczanowski, 1871). A. Orange female, Villa Teresa, La Paz Dept. B. Orange female with dark cephalic part, Riberalta, Beni Dept. C. Dark brown female, Villa Teresa, La Paz Dept. D. Dark brown male, same location. E. Pseudomyrmex simplex (Smith, 1877). F. P. tenuis (Fabricius, 1804). G. P. triplarinus (Weddell, 1850). H. P. gracilis (Fabricius, 1804). 
by Oliveira 1988). This constriction is another remarkable piece of indirect evidence for mimicry, as it is very likely disadvantageous by considerably reducing the reproductive output of these spiders, suggesting that survival rates are increased by mimicry. The unusually large eyes of Pseudomyrmex ants are imitated by large patches of dark pigments in light variants of Synemosyna spp. Given that the body shape of the involved species of Pseudomyrmex was very similar, species-specific mimicry became evident by similarity in body length and color.

\section{Polymorphic mimicry}

Based on the co-occurrence of specific color forms of Synemosyna with model species of Pseudomyrmex, Cushing (1997) suggested the presence of polymorphic mimicry. Polychromatic forms have been reported from five of the 17 known species of Synemosyna: S. americana (Galiano 1966; Cutler 1981b), S. aurantiaca (Galiano 1966; Oliveira 1988), S. decipiens (O. Pickard-Cambridge, 1896) (Cutler 1985), S. myrmeciaeformis (Taczanowski 1871; Peckham \& Peckham 1892), and S. smithi
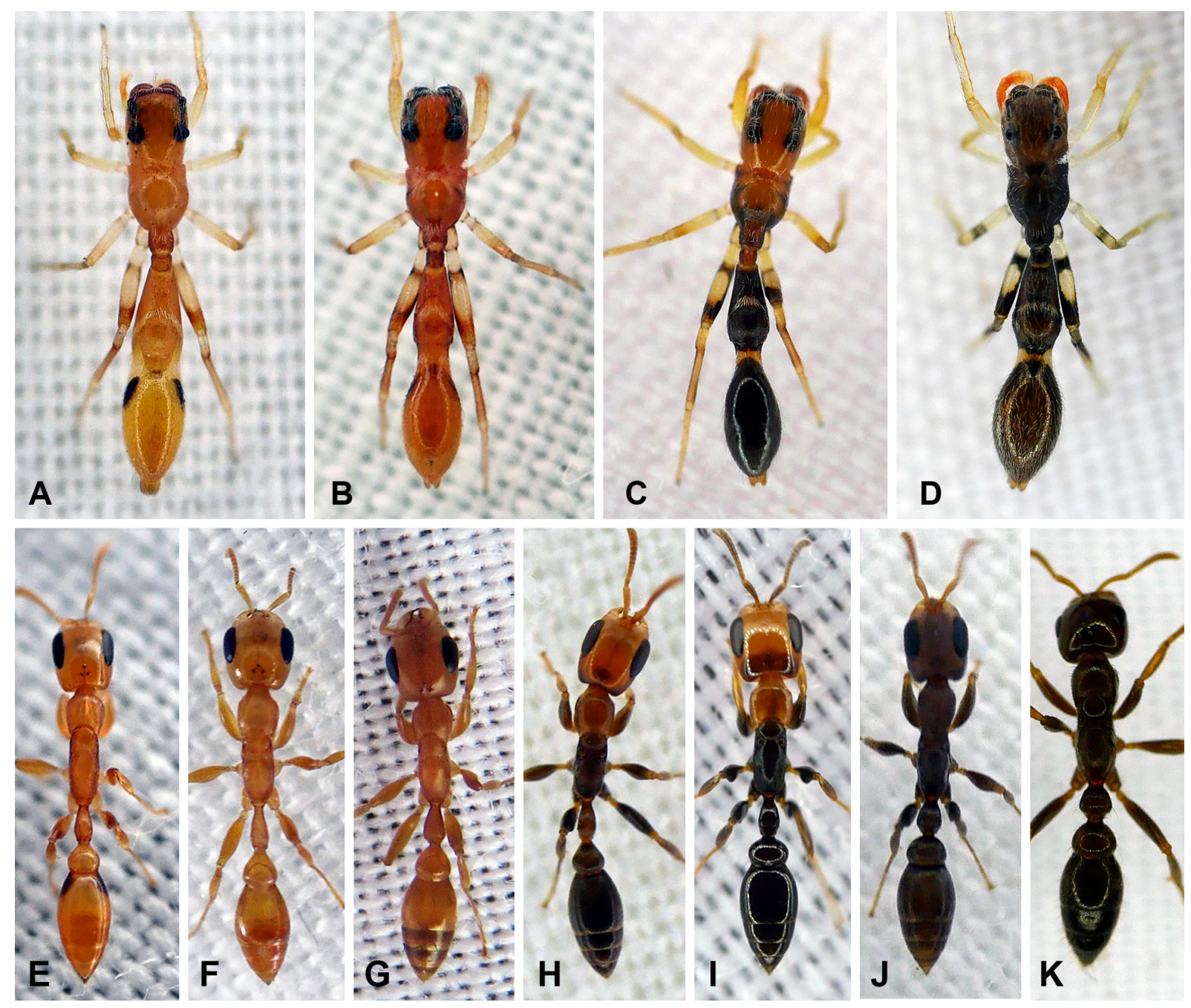

Fig. 9. A-D. Color variants and potential ant models for Synemosyna nicaraguaensis Cutler, 1993. A. Orange female, La Guardia, Santa Cruz Dept. B. Orange male, same location. C. Orange/black male, same location. D. Dark brown male, Villa Teresa, La Paz Dept. E. Pseudomyrmex simplex (Smith, 1877). F. P. cf. pallidus (Smith, 1855). G. Pseudomyrmex sp. H. P. filiformis (Fabricius, 1804). I. P. peruvianus (Wheeler, 1925). J. P. elongatus (Mayr, 1870). K. P. triplarinus (Weddell, 1850). 
Peckham \& Peckham, 1894 (Galiano 1966). However, specific ant models that may constitute a mimicry complex with polymorphic species of Synemosyna were only proposed for $S$. aurantiaca (reviewed by Cushing 1997). Light yellow or brown morphs of $S$. aurantiaca resemble P. flavidulus (Smith, 1858) and $P$. oculatus (Smith, 1855), while black morphs are similar to P. gracilis (Oliveira 1988). Galiano (1966) proposed P. phyllophilus (Smith, 1858) (cited as P. muticus) as the model for dark morphs of Argentinean S. aurantiaca.

In the present study, two possible mimicry patterns emerged, namely sex-specific polychromatic mimicry (S. nicaraguaensis) and transformational mimicry during ontogenetic development, involving smaller orange and larger, brown to dark-brown forms (S. aurantiaca and S. myrmeciaeformis, including larger orange forms with a black cephalic area in the latter) (Table 1; Figs 6, 8).

The high number of polychromatic forms in S. nicaraguaensis is likely advantageous because a lower number of mimics per model is assumed to increase the protection level for harmless models (Gilbert 2005). Mimicry complexes involving adult polymorphic jumping spiders were described for Myrmarachne in Australia (Pekár et al. 2017).

Complexes with transformational mimicry, strongly supported by co-occurrence patterns and size distribution, are here suggested for Synemosyna for the first time. Perger \& Rubio (2020a) reported mimicry complexes comprising forms with an ontogenetic change of ant-resemblance in the Simonellini genus Sympolymnia. Juveniles of S. lauretta (Peckham \& Peckham, 1892) and S. cutleri Perger \& Rubio, 2020 are potential mimics of black species of Crematogaster Lund, 1831, while juveniles of S. shinahota Perger \& Rubio, 2020 mostly resemble P. ethicus (Forel, 1911). Adults of the latter three species resemble small species of Camponotus Mayr, 1861. Considering the sympatry of several species of Sympolymnia and Synemosyna, selection for transformational mimicry that involves ants of different subfamilies may represent a mechanism fostering co-existence, thus increasing spider diversity.

Amongst ant-mimicking jumping spiders, transformational mimicry was observed in several African (Edmunds 1978) and Australian (Ceccarelli 2010) species of Myrmarachne MacLeay, 1839, and may occur in the majority of species of Myrmarachne (Wanless 1978). In Neotropical jumping spiders, transformational mimicry is also known from Zuniga magna Peckham \& Peckham, 1892. The juveniles of Z. magna resemble Camponotus ants, while the adult males imitate $P$. gracilis and the females Neoponera villosa (Fabricius, 1804) (Oliveira 1988). The limited knowledge of transformational mimicry in myrmecomorphic spiders, in general, is likely explained by the fact that many species are known only from adult individuals.

However, it may be hypothesized that transformational mimicry is common in ant-mimicking spiders with larger adults, assuming that juvenile spiders face at least the same level of predation pressure as adult spiders, and considering that ant models have castes occupying a discrete mode in the sizefrequency distribution. More detailed studies on model/mimic co-occurrence, abundance patterns and predator avoidance are needed to support the hypothesized relationships.

\section{Acknowledgments}

We extend many thanks to Wioletta Wawer (Museum and Institute of Zoology of the Polish Academy of Sciences, Warsaw, Poland) and Jean-Michel Maes (Museo Entomológico de León, Nicaragua) for providing photographs of important specimens, and to Philip S. Ward (Dept of Entomology and Nematology, University of California at Davis, USA) for helping with the determination of several species of Pseudomyrmex. We are very grateful to Bruce Cutler for the exchange of information on myrmecomorphic spiders, and to Adriano B. Kury (Museu Nacional, Universidade Federal do Rio de Janeiro, Brazil) for providing information on the status of type material. Joseph Schubert (Monash 
University, Clayton, Australia), José Fernández López (Museo Nacional Ciencias Naturales, Madrid, Spain) and the anonymous reviewer are thanked for improving the manuscript.

\section{References}

Ceccarelli F.S. 2010. New species of ant-mimicking jumping spiders of the genus Myrmarachne MacLeay, 1839 (Araneae: Salticidae) from North Queensland, Australia. Australian Journal of Entomology 49: 245-255. https://doi.org/10.1111/j.1440-6055.2010.00756.x

Ceccarelli F.S. 2013. Ant-mimicking spiders: strategies for living with social insects. Psyche 2013: 839181. https://doi.org/10.1155/2013/839181

Chamé-Vázquez D., Cutler B. \& Ibarra-Núñez G. 2020. Further taxonomic notes on the jumping spider Synemosyna maddisoni Cutler, 1985 (Araneae: Salticidae). Arthropoda Selecta 29 (4): 475-480. https://doi.org/10.15298/arthsel.29.4.10

Cushing P.E. 1997. Myrmecomorphy and myrmecophily in spiders: a review. Florida Entomologist 80 (2): 165-193.

Cutler B. 1981a. On a collection of antlike jumping spiders from Bolivia (Araneae: Salticidae). Studies on Neotropical Fauna and Environment 16: 51-55. https://doi.org/10.1080/01650528109360581

Cutler B. 1981b. Synemosyna bicolor is the female of Synemosyna americana (Araneae, Salticidae). Journal of Arachnology 9: 342-343.

Cutler B. 1985. Taxonomic notes on Neotropical species in the genus Synemosyna (Araneae: Salticidae). Studies on Neotropical Fauna and Environment 20: 83-91. https://doi.org/10.1080/01650528509360674

Cutler B. 1993. A new Middle American Synemosyna (Araneae: Salticidae). Revista nicaragüense de entomología 24: 1-4.

Cutler B. \& Edwards G.B. 2002. The jumping spiders (Araneae: Salticidae) of Trinidad and Tobago. Living World. Journal of the Trinidad and Tobago Field Naturalists'Club 2002: 39-44.

Cutler B. \& Müller H.G. 1991. The spider genus Synemosyna in northern Colombia (Araneae: Salticidae). Studies on Neotropical Fauna and Environment 26: 171-177.

https://doi.org/10.1080/01650529109360850

De Jager M.L. \& Anderson B. 2019. When is resemblance mimicry? Functional Ecology 13346: 13652435. https://doi.org/10.1111/1365-2435.13346

Deyrup M. 2016. Ants of Florida: Identification and Natural History. CRC Press, Boca Raton. https://doi.org/10.1201/9781315368023

Edmunds M. 1978. On the association between Myrmarachne spp. (Salticidae) and ants. Bulletin of the British Arachnological Society 4: 149-160.

Galiano M.E. 1966. Salticidae (Araneae) formiciformes V. Revisión del género Synemosyna Hentz, 1846. Museo Argentino de Ciencias Naturales Bernardino Rivadavia 1: 339-380.

Galiano M.E. 1967. Salticidae (Araneae) formiciformes. VIII. Nuevas descripciones. Physis. Revista de la Sociedad Argentina de Ciencias Naturales 27: 27-39.

Galiano M.E. 1971. Salticidae (Araneae) formiciformes. XII. Descripcion del allotypus de Synemosyna paraensis Galiano, 1967. Revista de la Sociedad Entomológica Argentina 33: 133-135.

Gilbert F. 2005. The evolution of imperfect mimicry. In: Fellowes M.D.E., Holloway G.J. \& Rolff J. (eds) Insect Evolutionary Ecology: 231-288. CABI, Wallingford, WA, USA. 
Ibisch P.L. \& Mérida G. 2003. Biodiversidad: La riqueza de Bolivia. Estado de Conocimiento y Conservación. Ministerio de Desarrollo Sostenible. Editorial Fundación Amigos de la Naturaleza (FAN), Santa Cruz, Bolivia.

Laborda Turrión Á. 2016. Comunidad de arañas isleñas en el río Uruguay: la diversidad en un corredor biológico. Tesis de maestría, Universidad de la República (Uruguay), Facultad de Ciencias.

Levi H.W. 1965. Techniques for the study of spider genitalia. Psyche 72: 152-158.

https://doi.org/10.1155/1965/94978

Maddison W.P. 2015. A phylogenetic classification of jumping spiders (Araneae: Salticidae). Journal of Arachnology 43: 231-292. https://doi.org/10.1636/arac-43-03-231-292

McIver J.D. \& Stonedahl G. 1993. Myrmecomorphy morphological and behavioral mimicry of ants. Annual Review of Entomology 38: 351-377. https://doi.org/10.1146/annurev.en.38.010193.002031

Mello-Leitão C.F. de 1917. Aranhas novas ou pouco conhecidas de Thomisidas e Salticidas brasileiras. Archivos da Escola Superior de Agricultura e Medicina Veterinaria, Rio de Janeiro 1: 117-153.

Mello-Leitão C.F. de. 1933. Ensaio sobre as myrmarachninas do Brasil. Boletim do Museu Nacional de Rio de Janeiro 9: 39-102.

Navarro G. \& Ferreira W. 2011. Mapa de Sistemas Ecológicos de Bolivia, escala 1:250000. Edición CD ROM. RUMBOL SRL-The Nature Conservancy (TNC), Bolivia.

Nelson X.J. \& Jackson R.R. 2012. How spiders practice aggressive and Batesian mimicry. Current Zoology 58: 620-629. https://doi.org/10.1093/czoolo/58.4.620

Oliveira P.S. 1988. Ant-mimicry in some Brazilian salticid and clubionid spiders (Araneae: Salticidae, Clubionidae). Biological Journal of the Linnean Society 33: 1-15.

https://doi.org/10.1111/j.1095-8312.1988.tb00443.x

Olson D.M., Dinerstein E., Wikramanayake E.D., Burgess N.D., Powell G.V.N., Underwood E.C., D’Amico J.A., Itoua I., Strand H.E., Morrison J.C., Loucks C.J., Allnutt T.F., Ricketts T.H., Kura Y., Lamoreux J.F., Wettengel W.W., Hedao P. \& Kassem K.R. 2011. Terrestrial ecoregions of the world: a new map of life on Earth. BioScience 51 (11): 933-938.

https://doi.org/10.1641/0006-3568(2001)051[0933:TEOTWA]2.0.CO;2

Pearson D.L., Guerra J. \& Brzoska D. 1999. The tiger beetles of Bolivia: their identification, distribution and natural history (Coleoptera: Cicindelidae). Contributions on Entomology, International 3 (4): $382-$ 523.

Peckham G.W. \& Peckham E.G. 1885. On some new genera and species of the Attidae, from Madagascar and Central America. Proceedings of the Natural History Society of Wisconsin 1885: 23-42.

Peckham G.W. \& Peckham E.G. 1892. Ant-like spiders of the family Attidae. Occasional Papers of the Natural History Society of Wisconsin 2 (1): 1-84.

Available from https://www.biodiversitylibrary.org/part/82774 [accessed 5 Mar. 2021].

Peckham G.W., Peckham E.G. \& Wheeler W.H. 1889. Spiders of the subfamily Lyssomanae. Transactions of the Wisconsin Academy of Sciences, Arts and Letters 7: 222-256.

Pekár S., Petráková L., Bulbert M.W., Whiting M.J. \& Herberstein M.E. 2017. The golden mimicry complex uses a wide spectrum of defence to deter a community of predators. eLife 6: e22089.

https://doi.org/10.7554/eLife.22089.001

Perger R. 2015. The highest known euglossine bee community from a garden in the Bolivian Andes (Hymenoptera, Apidae, Euglossini). Journal of Hymenoptera Research 45: 65-73.

https://doi.org/10.3897/JHR.45.5003 
Perger R. \& Grossi P.C. 2013. Revision of the rhinoceros beetle genus Oryctophileurus Kolbe with description of a new species, the male of $O$. varicosus Prell, and notes on biogeography (Scarabaeoidea, Dynastinae, Phileurini). ZooKeys 346: 1-16. https://doi.org/10.3897/zookeys.346.6114

Perger R. \& Perger Y.N. 2017. A species richness hotspot of ant-mimicking sac spiders (Araneae: Corinnidae: Castianeirinae) at the Bolivian Orocline, with new country records for three genera and nine species. Annals of the Entomological Society of America 110 (4): 403-408.

https://doi.org/10.1093/aesa/sax040

Perger R. \& Rubio G.D. 2018. A wolf in sheep's clothing: the description of a fly resembling jumping spider of the genus Scoturius Simon, 1901 (Araneae: Salticidae: Huriini). PLoS ONE 13 (1): e0190582. https://doi.org/10.1371/journal.pone.0190582

Perger R. \& Rubio G.D. 2020a. Sympolymnia, a new genus of Neotropical ant-like spider, with description of two new species and indirect evidence for transformational mimicry (Araneae, Salticidae, Simonellini). Zoosystematics and Evolution 96 (2): 781-795. https://doi.org/10.3897/zse.96.55210

Perger R. \& Rubio G.D. 2020b. Contributions to the knowledge of Neotropical ant-like spiders: Myrmecotypus tahyinandu sp. n. from Bolivian Chiquitano forest, a new country record for M. niger, and indirect evidence for species-specific mimicry (Araneae: Corinnidae: Castianeirinae). Zootaxa 4790 (1): 151-164. https://doi.org/10.11646/zootaxa.4790.1.9

Piza Jr. S. de T. 1937. Novas especies de aranhas myrmecomorphas do Brasil e considerações sobre o seu mimetismo. Revista do Museu Paulista 23: 307-319.

Podgaiski L.R., Ott R., Lopes Rodrigues E.N., Buckup E.H. \& Leão Marques M.A. 2007. Araneofauna (Arachnida; Araneae) do Parque Estadual do Turvo, Rio Grande do Sul, Brasil. Biota Neotropica 7 (2): 1-15. https://doi.org/10.1590/S1676-06032007000200023

Raizer J. 2004. Comunidade de aranhas em capões de mata das sub-regiões Miranda e Abobral no pantanal sul-mato-grossense. $\mathrm{PhD}$ Thesis, Universidade Estadual de Campinas.

Rodrigues E.N.L., Mendonça J.M.S. \& Ott J. 2009. Spider diversity in a rice agroecosystem and adjacent areas in southern Brazil. Revista Colombiana de Entomología 35 (1): 89-97.

Rodrigues E.N.L., Rodrigues P.E.S., Mendonça J.M.S. \& Milton S. 2016. Spider species composition in the tree-shrub strata of riparian forests and its microhabitats in southern Brazil. Zoologia (Curitiba) 33 (3): e20150102. https://doi.org/10.1590/S1984-4689zool-20150102

Simon E. 1901. Histoire naturelle des Araignées. Deuxième édition, tome second. Roret, Paris. https://doi.org/10.5962/bhl.title.51973

Taczanowski L. 1871. Les aranéides de la Guyane française. Horae Societatis entomologicae Rossicae 8: $32-132$.

Wanless F.R. 1978. A revision of the spider genera Belippo and Myrmarachne (Araneae: Salticidae) in the Ethiopian region. Bulletin of the British Museum (Natural History), Zoology 33: 1-139. Available from https://www.biodiversitylibrary.org/part/28732 [accessed 5 Mar. 2021].

Wappes J.E., Lingafelter S.W. \& Perger R. 2011. Additions and deletions to the known Cerambycidae (Coleoptera) of Bolivia. Insecta Mundi 0150: 1-8.

Available from https://digitalcommons.unl.edu/insectamundi/669/ [accessed 5 Mar. 2021].

World Spider Catalog. 2020. World Spider Catalog. Version 19.5. Natural History Museum Bern. Available from http://wsc.nmbe.ch [accessed 10 Sep. 2020].

Zapata L.V. \& Grismado C.J. 2015. Lista sistemática de arañas (Arachnida: Araneae) de la Reserva Ecológica Costanera Sur (Ciudad Autónoma de Buenos Aires, Argentina), con notas sobre su taxonomía 
y distribución. Revista del Museo Argentino de Ciencias Naturales 17 (2): 183-211. Available from https://ri.conicet.gov.ar/handle/11336/46712 [accessed 5 Mar. 2021].

Manuscript received: 12 October 2020

Manuscript accepted: 12 January 2021

Published on: 5 May 2021

Topic editor: Rudy Jocqué

Desk editor: Pepe Fernández

Printed versions of all papers are also deposited in the libraries of the institutes that are members of the EJT consortium: Muséum national d'histoire naturelle, Paris, France; Meise Botanic Garden, Belgium; Royal Museum for Central Africa, Tervuren, Belgium; Royal Belgian Institute of Natural Sciences, Brussels, Belgium; Natural History Museum of Denmark, Copenhagen, Denmark; Naturalis Biodiversity Center, Leiden, the Netherlands; Museo Nacional de Ciencias Naturales-CSIC, Madrid, Spain; Real Jardín Botánico de Madrid CSIC, Spain; Zoological Research Museum Alexander Koenig, Bonn, Germany; National Museum, Prague, Czech Republic. 